Marquette University

e-Publications@Marquette

Social and Cultural Sciences Faculty Research and

Publications

Social and Cultural Sciences, Department of

$1-1-2015$

\title{
Exoffender Accounts of Successful Reentry from Prison
}

Heather R. Hlavka

Marquette University, heather.hlavka@marquette.edu

Darren Wheelock

Marquette University, darren.wheelock@marquette.edu

Richard S. Jones

Marquette University, richard.jones@marquette.edu

Accepted version. Journal of Offender Rehabilitation, Vol. 54, No. 6 (2015): 406-428. DOI. (C) 2015

Taylor \& Francis (Routledge). Used with permission. 


\title{
Exoffender Accounts of Successful Reentry from Prison
}

\author{
Heather Hlavka \\ Department of Social and Cultural Sciences, \\ Marquette University, \\ Milwaukee, WI \\ Darren Wheelock \\ Department of Social and Cultural Sciences, \\ Marquette University, \\ Milwaukee, WI \\ Richard Jones \\ Department of Social and Cultural Sciences, \\ Marquette University, \\ Milwaukee, WI
}

Reentry research often focuses on those who have recidivated, with little work addressing the experiences of those who successfully reintegrate into their communities. This study examines individual accounts of successful transitions from prison to community in the months and years postrelease. Interview data point to three metanarratives used to make sense of reentry: as reverence, as reunification, and as reconstruction. In different ways, each 
NOT THE PUBLISHED VERSION; this is the author's final, peer-reviewed manuscript. The published version may be accessed by following the link in the citation at the bottom of the page.

narrative centers on connections to important others through faith, family, or community. We discuss the legitimacy of the self-narratives offered, and add to a growing body of work exploring reentry via the lens of the exoffender.

Keywords: offender reentry, qualitative research, reentry, reintegration, role transformation

Over the last two decades, social scientists have paid considerable attention to the complex and diffused impact of criminal punishment on the lives of the punished. In 2008, the Pew Center on the States found that one out of every 100 American adults was incarcerated, yet 734,144 inmates were released that same year (Carson \& Golinelli, 2014). While incarceration rates have declined steadily since, by the end of 2013 a total of 637,411 men and women were released from custody while over 2.2 million individuals remained confined (Carson \& Golinelli, 2014; Glaze \& Kaeble, 2014). Of those incarcerated, over 1.5 million prisoners were housed in state and federal prisons (Carson, 2014) and 731,200 were held in local jails (Glaze \& Kaeble, 2014). Imprisonment alone, however, does not capture the full picture of mass incarceration. An additional 4.75 million men and women were under community supervision in 2013.

Many of these individuals represent the most marginalized members of society, as released inmates tend to suffer from a multitude of personal and social difficulties. Research has found that released prisoners tend to have spotty work histories (Apel \& Sweeten, 2010; Hlavka, Wheelock, \& Cossyleon, 2015), are frequently uneducated or undereducated (Petersilia, 2003), and often live with family members with legal troubles of their own (Visher, Yahner, \& La Vigne, 2010). In addition, many jurisdictions prohibit individuals with felon status from a wide range of civic, educational, and employment opportunities (Wheelock, 2005; Wheelock \& Uggen, 2008; Wheelock, Uggen, \& Hlavka, 2011), and the low-wage labor market continues to discriminate against individuals with a criminal record (Pager, Western, \& Bonikowski, 2009).

Almost $77 \%$ of inmates are rearrested and slightly more than $55 \%$ are reconvicted of a new offense within 5 years of release (Durose, Cooper, \& Synder, 2014). Understandably, social scientists have focused on the factors that lead so many released prisoners to recidivate. Focusing solely on so-called failed cases overlooks the 
experience of a significant minority of individuals who avoid returning to prison (Richards \& Jones, 2004). Despite the challenges, some individuals do manage to navigate the reentry process. This study examines the narratives used to account for their success.

Reentry-the return home from prison-is not a static event. It is fundamentally a social process that incorporates life prior to prison, life in prison, immediate release from prison, and the years that follow (Visher \& Travis, 2003). Factors such as personal motivation, social networks, new social roles, available social supports, and lifestyle changes can uniquely shape released prisoners' experiences with reentry (Bushway, Piquero, Broidy, Cauffman, \& Mazerolle, 2001; Laub \& Sampson, 2001; Travis \& Petersilia, 2001). Preprison commitments and identities (Nelson, Deess, \& Allen, 1999; Sampson \& Laub, 1993) and in-prison experiences like programming and religious conversions (Maruna, Wilson, \& Curran, 2006; Petersilia, 2003; Ross \& Richards, 2002; Schmid \& Jones, 1991) can also impact one's ability to adjust to life beyond incarceration. For some, preprison stakes in conformity and ties to conventional roles and relationships are especially important. The importance of healthy bonds to family and community cannot be overstated (Herschaft, Veysey, Tubman-Carbone, \& Christian, 2009; O’Brien, 2001; Laub, Nagin, \& Sampson, 1998; Uggen, 2000; Wakefield \& Wildeman, 2014; Warr, 1998). The family can serve as an important "agent of re-socialization" into the free world (La Vigne, Visher, \& Castro, 2004; Visher, Kachnowski, La Vigne, \& Travis, 2004). For others, however, cutting ties with family members and prior associates might facilitate criminal desistence (Warr, 1998).

For this study, we explore individual pathways in the transition from prison to community in the months and years following release. For most exoffenders, employment remains a cornerstone to reentry, yet many are unable to find legitimate opportunities for employment (Solomon, Roman, \& Waul, 2001; Uggen \& Thompson, 2003). For some, just the possibility of finding work demonstrates conventional commitments and by extension facilitates reentry (Hlavka et al., 2015). Research also identifies the importance of role transformation and commitment to family (Herrschaft et al., 2009; O'Brien, 2001; Uggen \& Thompson, 2003) as well as civic participation and neighborhood involvement (Maruna, 2001; Travis \& Petersilia, 2001; 
Uggen \& Thompson, 2003). Transformations often begin in-prison. For example, Jones and Schmid (2000) found that first-time inmates suspend much of their preprison identity in order to transform and adapt to carceral environments, creating a new perspective for selfevaluation. In a similar vein, Maruna's (2001, p. 7) work posits that desistance is only possible when released prisoners "develop a coherent pro-social identity for themselves." Reintegration thus requires a new, willful perspective on life-a revision of aspirations and an increasing concern for others. The reinvention of personal narratives is consistent with extant reentry research that highlights identity reorientation as an important path to reform; one needs to make sense of and move past criminal pasts and punishment even though individuals don't always discard their deviant identities (Brown, 1991a, 1991b).

\section{Narratives of Reentry and Reform}

Research suggests that successful reentry requires a reorientation of self, derived from prior experiences and identities, but attached to conventional roles and institutions. Autobiography and self-identity are redefined in light of new experiences (Giddens, 1991) and research on postprison experiences demonstrates powerful narratives of redemption and transformation (Herrschaft et al., 2009; Irwin, 1970; Jones \& Schmid, 2000; Maruna, 2001; O’Brien, 2001; Richie, 2001; Gadd \& Farrall, 2004). Drawing from Goffman (1963) and Mead (1934), subjective accounts of reentry suggest that a reorientation of one's identity and self-concept might be necessary for individuals to make sense of and move past their criminal past. Caught between being discredited and being discreditable (Goffman, 1959), respondents in Maruna's (2001) study developed unique identity management strategies, dependent upon the adaptation of specific cultural scripts. Maruna suggested that explanations of desistance from crime might be strengthened by narrative accounts (also see Harding, 2003; Hlavka et al., 2015; Kaufman \& Johnson, 2004; McAdams, 1993). Exoffenders often explain reform as a process of self-transformation and personal decision-making rather than something managed by outside agencies (Maruna et al., 2009). Finding catalysts or "hooks" (Giordano, Cernkovich, \& Rudolph, 2002) 
for lasting change and reform was critical, and often relied on others' positive reinforcement and support of the exoffender.

Taken together, we understand narratives of reentry as the product of an individual's suspended and adaptable identity, experiences in prison, and the ability to manage public stigma upon release (Harding, 2003; Maruna, 2001; Schmid \& Jones, 1991; Maruna, Wilson \& Curran, 2006). Drawing on interviews with exoffenders, we ask how respondents experience and adapt to returning to the free world following incarceration: What types of narratives emerge to account for managing spoiled identities and creating new ones? What is their purpose and appeal? Cultural scripts, attributions, and adaptations provide useful tools for understanding how exoffenders manage stigmatized identities (Goffman, 1963) as they navigate reentry. We contend that the particular narratives offered by exoffenders who have successfully reentered reveal the social scripts available to replace the "felon label" (Cohen, 1965) with a new social identity that holds purpose, meaning, and a sense of control in a world where they have few tangible options or opportunities. The interview data were thematically arranged and categories delineated to better understand how some exoffenders, despite profound social barriers, successfully reentered their communities. The predominant narratives used to account for this process centered on relationships with God, faith, and others explained as narrative accounts of reentry vis-à-vis reverence, reunification, and reconstruction.

\section{Method}

We conducted 58 audiotaped, face-to-face, in-depth interviews with 24 women and 34 men identified as former offenders actively participating in two nonprofit organizations in Milwaukee, WI. The two distinct but similar programs have longstanding local reputations for assisting individuals with criminal records. Client participation is voluntary and both organizations are faith based. They emphasize mentorship and accountability while assisting with job-search activities and work-skills development. Wraparound services are included based on client, including Alcohol and Other Drug Abuse (AODA) meetings, ${ }^{1}$ 
support groups and counseling, courses in parenting, and anger management classes. This study was designed in partnership with both programs.

Out of 58 total participants, 47 interviewees (29 men and 18 women) were considered by caseworkers of each respective organization to be successful former offenders. These men and women met the criteria of having been released from incarceration for a minimum of 3 years and had no known new arrest(s), conviction(s), or parole violation(s). Participants included those who had successfully completed probation or parole and those still under formal supervision. The majority of our study respondents were Black ( $n 1 / 430)$ followed by White (n1/413), Hispanic/Latino ( $n 1 / 43)$, and biracial ( $n 1 / 41)$. They were convicted of a variety of crimes including murder, manslaughter, rape, aggravated assault, possession of drugs, arson, armed robbery, burglary, prostitution, theft, and fraud (violent, $n 1 \frac{1}{4} 11$; sex offense, $n 1 / 46$; drugs, $n^{1 / 414}$; property, $n^{1 / 416)}$.

In-depth interviews were conducted at a time arranged by one researcher and one respondent in a private meeting space to assure confidentiality. Interview length averaged $90 \mathrm{~min}$. Based on prior research, semi-structured interview questions covered seven primary categories: (a) background and case history; (b) stressful life events and reintegration (e.g., routine activities, barriers to reentry); (c) employment and education (e.g., employment status, future goals; Pager, Western, \& Sugie, 2009); (d) family and support systems (e.g., Herrschaft et al., 2009; Travis \& Waul, 2003); (e) voting practices and understandings of current laws (e.g, Uggen et al., 2006); (f) reoffense and reintegration (turning points and transitions experienced); and for those that qualified, (g) sexual offender-specific questions (e.g., community notification and sex offender registry). ${ }^{2}$ Interviews were transcribed verbatim according to Human Subject Protocol. ${ }^{3}$ Informed consent forms were read and explained to respondents. Confidentiality was further assured by allowing the respondents in the sample to choose their own pseudonyms when desired. Pseudonyms were used at all stages of data collected and analyses, and other identifying information was changed or removed from the transcripts. 
NOT THE PUBLISHED VERSION; this is the author's final, peer-reviewed manuscript. The published version may be accessed by following the link in the citation at the bottom of the page.

\section{Coding and Analysis}

Using a narrative constructionist approach, we explored how exoffenders accounted for their reentry successes. Narrative is a way of both making sense of one's lived experience and a way of sharing that understanding with others (Gergen, 1999). Self-narratives are used to construct, explain, and account for one's life in relation to others. Gubrium and Holstein (1997) described "narrative practice" as the ordering of a story that makes an otherwise chaotic narrative meaningful and reportable. The coherence and meaning of the story emerges through "narrative linkages," or how the storyteller brings together a complex grouping of objects (Gubrium \& Holstein, 1997). Individuals must choose from a variety of possible discourses and cultural scripts to create linkages and construct their story (Gubrium \& Holstein, 1998).

A qualitative, analytic-inductive method (Patton, 1990) was combined with analytic bracketing throughout the coding and analysis of our study. Inductive analysis requires immersion in the details and specifics of the data as one builds toward general patterns and interrelationships (Patton, 1990). Categories are not imposed; rather they emerge from the data (Glaser \& Strauss, 1967). Analytic bracketing searches for commonalities among individual subjectivities according to descriptions of what respondents experienced (description) and how it was that they account for what they experienced (construction). Interviews were content analyzed and coded using Atlas. TI, a qualitative data analysis software program. Atlas. TI allows for data retrieval and sharing for cross-classification and cross-comparison coding. Following the inductive approach outlined by Patton (1990), open coding of transcripts was blindly completed by the authors and compared in a constructive manner (Morse, Barrett, Mayan, Olson, \& Spiers, 2002). Following open-coding discussions during first-round coding, authors agreed on classification schemes and a coding procedure was developed. While respondents had unique stories to tell the interviewers, exoffenders also shared a number of commonalities as they accounted for successful reentry. 
NOT THE PUBLISHED VERSION; this is the author's final, peer-reviewed manuscript. The published version may be accessed by following the link in the citation at the bottom of the page.

\section{Findings}

Study respondents faced a wide range of challenges to reentry such as finding stable housing and employment in poor economic conditions. While some exoffenders secured basic necessities, others struggled with temporary work agencies and discrimination. Common threads in respondents' stories were experiences with stigmatization and shame. Several respondents revealed their frustration and embarrassment over repeatedly "coming clean" with employers and others. Shame-based parole requirements (Braithwaite, 1989) often intensified this guilt and embarrassment. Sarah's (female) parole officer asked for verification of her whereabouts at all times, requiring signed forms from potential employers.

Just being there [applying for a job] and having to get verification. If you have to explain that to someone it's embarrassing and some people don't understand. They look at you like, what is this for? And I have to write down the time I got there, the time I left. I have to do that for the doctor, for jobs, for anywhere I go. Everyplace I go, I have to get verification...that was more my issue-like being embarrassed.

Many interviewees specifically mentioned being labeled with an " $F$ " for felon:

It seems like I was given a scarlet $\mathrm{F}$ to wear around on my forehead the rest of my life. You know, it's an F for felon and nobody will touch it with a 10 -foot pole and so it seems like kind of a lifetime conviction. (Paul, male)

Akin to Goffman's (1963) master status, respondents spoke of spoiled identities as impossible to completely shed.

These interview data demonstrate that overcoming the master status of the felon label is an essential step on the path towards successful reentry. In specifying the processes of role transition, coherent narratives of change are crucial among exoffenders as they aim to make sense of major life transitions like reentry reintegration. Simply put, exoffenders need to make sense of their lives with narratives of purpose and meaning. In our examination, important 
commonalities existed among respondents identified as successes, revealing how common cultural scripts are infused in meaningful stories of reentry and reform. They developed understandings of their prior selves and described transformations similar to what Maruna (2001) called "redemption scripts." Respondents recounted cognitive shifts in roles and identities that were largely interconnected with important others in their lives. By and large, their narratives highlighted their relational and emotional needs rather than material necessities. The three emerging categories emphasized "making good" in their communities via socially approved avenues that specifically focused on God and others. The categories were not mutually exclusive of each other. In fact, respondents narrated their stories in ways that focused on positive outcomes that emerged from their difficult circumstances, so for many, their deviant identities may have been compartmentalized but their criminal pasts remained central to their identities. Material barriers to reentry, such as lack of employment opportunities, were described as important challenges to reentry, but reform was predicated on self-efficacy and personal transformations aided by others.

\section{Accounts of Reentry as Reverence}

Reentry as reverence ( $n 1 / 415 ; 10$ men, 5 women) characterized respondents who accounted for reentry and reform through faith and religious devotion. Religious conversions are not uncommon in prison (Maruna et al., 2006) and they are frequently given credit for facilitating personal transformation: "The change in me is true and that the resurrection of Jesus Christ is walking around, you know, alive and well, present in me. You know, I really do have a resurrected life" (Bob, male). While accounts were sometimes linked with stories of divine intervention or deliverance, respondents consistently referenced personal relationships and credited family members (parents, children, partners), friends, caring professionals (therapists, mentors, counselors, employers, advocates), and religious figures (God, clergy) for providing support and love as they struggled to reintegrate.

Despite generally being an unpleasant and difficult place to reside, prison has also been described as a place of reflection and solitude (Irwin, 1970; Schmid \& Jones, 1991). Michael (male) recalled 
how prison allowed the time for him to come face-to-face with the consequences of his previous actions:

So, [prison] definitely made you think about that, you know. You away from your family, you know, your children and everything that you never thought about the consequences until it came and then, you know, you came face-to-face with it.

For some respondents, additional time for reflection facilitated interest in Bible studies and other faith-based programs. Conversion was indeed an accepted meta-narrative of forgiveness both in and outside of prison. Physically separated from the rest of society and removed from many of the difficulties faced prior to incarceration, God symbolized the acceptance and forgiveness respondents needed in order to internalize self-worth, meaning, and purpose in life:

"Forgiving and forgetting is a whole different story....If you truly are forgiven, and you love them, and you love them in God, you don't judge them" (Bob, male). Once the conversion was made, for some, it was all consuming. Rodger (male) shared that he "accepted Christ down in the county jail":

As a rule, I would just sit in the corner with my back to the wall and just watch people, and this one guy just came up and he asked me...you know, the Bible studies....And I read Romans 10, 9 and 10, and I, well, if that's all God wants is for somebody just to believe Him, I can do that, and said, He wants my sin to give me His righteousness, well, that's all. I made the exchange and then, after that, I started reading. I had a hunger for the Scripture, I mean, the words just jumped off the page. And I could, I couldn't get enough of it. I would rather read than eat food.

For some, incarceration was an essential step on the path to redemption because it represented the "bottoming out" often associated with self-transformation or conversion, not altogether uncommon sentiments for individuals released from prison (also see Johnson, Larson, \& Pitts, 1997; Maruna et al., 2006). In fact, faith and religious communities often provide a way of life that is "fundamentally incompatible with continued deviation" (Giordano, Cernkovich, \& Rudolph, 2002, pp. 1000-1001). 
NOT THE PUBLISHED VERSION; this is the author's final, peer-reviewed manuscript. The published version may be accessed by following the link in the citation at the bottom of the page.

Exoffenders spoke of their newfound empowerment through faith; they believed that God walked side-by-side with them and took care of challenges that were beyond their control:

If it wasn't for God, I think I would probably-I wouldn't be sitting here talking to you right now. But, because of God, I am able to sit here todayand have this conversation with you. As long as, you know-with God's help, I'm gonna say that on my own, I probably would have been...but with God's help, I'll never be back there. (Derek, male)

Respondents' often described faith and God as motivators. In response to the interviewer's question about how he stays out of trouble and off the streets, Jay (male) explained:

Man, all I can say is church, conviction, God. Like, just going to church and seeing people successful in church. Knowing that if I just continue on, you know. I think that the reason that I'm having such a hard time finding a job, I think it's not a physical thing, I think it's a spiritual thing to see if I'm really, really gonna hold on.

Like others, Jay described unemployment as a spiritual test of his will and strength. Faith and action went hand-in-hand; exoffenders self-described as personal agents, making important decisions and choices with God's help:

I define success as my relationship with Jesus because everything that I do is tied into Jesus. He's the one that has changed me, given me the faith to even believe in Him the way that I do. It's all connected to Jesus, you know, but then me and myself, you know. He gave me the ability to do what I do, so everything is tied in with Him. But one thing that he has allowed me is to make the right choice, so my success is tied in with Jesus through him helping me and giving me the information to make the right choices. (Jay, male)

Respondents were able to mitigate their shameful pasts and replace the label of criminal by becoming an agent of God. Through faith, they discovered self-love and were able to forgive themselves for past sins. One respondent explained: 
NOT THE PUBLISHED VERSION; this is the author's final, peer-reviewed manuscript. The published version may be accessed by following the link in the citation at the bottom of the page.

Jesus said you have to love your neighbor...you got to appreciate yourself first, the way God made you. And I think that's one of the major things that's helping me stay on my track, is my love for myself.

Our interview data also demonstrate that religious identity facilitates connections through which respondents were able to establish social capital and a "reintegrative community" (Braithwaite, 1989). Interviewees reported developing new conventional social ties with individuals through religious mentors, participation in religious services, and other faith-based activities. Stephen (male) told the interviewer that while in prison, he started "sharing [the Bible] and then started letting people also come into [his] life at that time." For Stephen, faith opened up numerous avenues of material and social support. His religious mentor in prison introduced him to another religious couple: "she and her husband were just like a brother and sister to me, so that was the real connection of letting people come back into my life."

Networks of faith-based communities and the dense social networks that often formed through these religious groups kept respondents embedded in conventional and normative behaviors. Respondents felt connected to others and to something larger than themselves; they respected and felt obligated to abide by the rules and norms of religious communities. Functioning as social capital, these relationships also connected released prisoners to wider networks beyond religious communities including schools, self-help groups, and nonprofit programming. Several respondents were introduced to nonprofit organizations through their religious mentors, many were connected to employment opportunities, and others gained opportunities for speaking engagements in high schools and colleges:

[Church] provided the opportunity for me to be able to go into the schools and talk to at-risk students. They had a prison minister there. I had an opportunity to work with this woman, she's a schoolteacher, and I used to do presentations throughout [the] schools, and I had an opportunity to do some of those for her school. (Lily, female)

For Lily, the church was a resource of intrinsic value that provided her with meaning and self-worth in otherwise difficult

Journal of Offender Rehabilitation, Vol. 54, No. 6 (2015): pg. 406-428. DOI. This article is @ Taylor \& Francis (Routledge) and permission has been granted for this version to appear in e-Publications@Marquette. [Taylor \& Francis (Routledge) does not grant permission for this article to be further copied/distributed or hosted elsewhere without the express permission from Taylor \& Francis (Routledge). 
NOT THE PUBLISHED VERSION; this is the author's final, peer-reviewed manuscript. The published version may be accessed by following the link in the citation at the bottom of the page.

circumstances. Newly formed social networks ultimately fostered generative pursuits aimed at helping others.

\section{Accounts of Reentry as Reunification}

Respondents who accounted for reentry success through reunification ( $n 1 / 419 ; 11$ men, 8 women) often emphasized the intensity of being separated from loved ones while incarcerated. Some respondents reported inconsistent and unreliable familial and partner support. Limited family visits, institutional transfers, and far-removed prison locations often made family contact difficult or as one respondent stated: "Out of sight, out of mind" (Joy, female). Some interviewees felt deserted by loved ones, while others decided to end relationships that were already strained or unhealthy. Reentry success, however, is closely tied to feeling accepted in society, and that often begins with acceptance from family and others.

Respondents mourned the time lost with family, especially children, and reflected on how their criminal behavior and incarceration had affected others. Many sought to make amends:

Seeing my daughter has changed my life because when she was born I was currently locked up. I wasn't there for either one of my kids' birth. And I feel less of a man and less of a persontype thing. (Jack, male)

James also felt like less of a man for abandoning his wife and not raising his children: "For me to be in and out of this life, like going to jail, getting out, then going back to jail. I just feel less of a man to keep running in and out." Damian echoed these sentiments in his remarks on the impact of incarceration:

So, I was stressing trying to raise my kids from the penitentiary. My second daughter, she was 14 when I left. I get out the door, she got three kids. And I blame myself because I wasn't there to protect her. And I lost a lot of people, family members, brother, my auntie that raised me, a mother-in-law that I was crazy about...I lost a lot of people. I didn't get a chance to get that last respects....It took my youngest daughter to tell me, "Daddy, I don't care if you don't never buy us nothing. We just need you out here." And that touched me, you know? 
Damian lamented the time he lost with his children and the loved ones, and reunification was paramount. When asked what was necessary to help exoffenders reintegrate and reform, Chad (male) explained: "Number one, getting reunited with their family once you have been incarcerated" followed by education and support groups. Reintegration into family life certainly had its obstacles-time lost, legal termination of parental rights to name a few-but many respondents wanted the chance to reunite with families and be good role models for their children. Connections to family and partners provided respondents with motivation to succeed as well as a heightened sense of self. Men and women alike talked about raising their kids from prison, vowing never to return:

My plan is never to go to prison again, and be out here for my kids and be a mother and do what I need to do... who gonna be there for my kids, my boys almost teenagers? You know, that's how I don't get involved back in criminal activities cause I think about, okay, if I do this, this is the repercussion that I get. (Jess, female)

Bonds to marriage and family served as significant turning points for exoffenders as well. Chris (male) talked about his spouse as an essential to his successful reentry: "I have a wife. I got married, and that was like the biggest moment of my life was getting married, having that stability, have a family you know. Even since then, it's been like, the door is wide open." An intimate partner can be a turning point or a hook for change and trigger desistance by helping respondents manage marginalized and stigmatized identities. Damian explained how a "new woman" kept him busy, away from deviant peers, and in church. Ultimately, she helped Damien develop a prosocial identity, providing him meaning and hope:

I have a new woman in my life that keeps me up on my feet. That's what I'm saying. I didn't believe in church and all that stuff before I went in. But now I want to believe in something. You know what I'm saying? So, I look forward to going to church with her. Although I might not understand it, but it's something for me to do, to keep me busy. And hope. I'm looking for hope. You know what I'm saying? She got a lot of confidence into me. I feel bad if I let her down. So, I'm going 
NOT THE PUBLISHED VERSION; this is the author's final, peer-reviewed manuscript. The published version may be accessed by following the link in the citation at the bottom of the page.

my best to stay out of there, because, like I say, all my life I been locked up.

Support from family and intimate partners was a lifeline for many exoffenders. For some, it was described as a matter of life or death:

I think honestly, if I didn't have the family support, I probably would have stayed in Texas and went back to the same people and either end up dead or in prison for the rest of my life. With the family support, that's huge. And that's what I tell people, you gotta keep in contact with these guys. (Dereck, male)

Respondents embraced new responsibilities and roles that came with renewed family connections and commitments. Many talked about being "a grown-up now" or becoming a "real man" through commitment to children and partners: "I changed my whole lifestyle. I'm a grownup now. When you get older, you act as an example for your kids and your grandkids" (Veronica, female). Because most respondents had children before going to prison, that condition alone did not promote successful reentry. It is likely that aging out of youthful offending, combined with developing social bonds to conventional roles like work and family, had much to do with many exoffenders' successes. Certainly, a heightened sense of commitment was a powerful motivator but role identity transformation had to be both salient and supported by actual tangible resources.

I'm a man now, you know. I have a family. And the fact that, you know, what my mother's going through. I don't have that much family here, but I have to look out for them. I'm the oldest grandson. I mean, there's just too much to lose now to be thinking about doing anything. And plus, I'm more mature. I'm not a boy anymore. I'm a man. When you're a boy, you're irrational. You're not thinking. But as a man, you start thinking like, okay, this is not what you need to be doing. This is not kosher for society, for you and your family. So, just the fact that you just want a better life for yourself. (Dre)

For Dre, being a "man" meant being mature and rational, and thinking about others. In his words, a better life included doing what was right for this family, but also for society-to contribute to a "greater common good." Other respondents spoke of becoming

Journal of Offender Rehabilitation, Vol. 54, No. 6 (2015): pg. 406-428. DOI. This article is @ Taylor \& Francis (Routledge) and permission has been granted for this version to appear in e-Publications@Marquette. [Taylor \& Francis (Routledge) does not grant permission for this article to be further copied/distributed or hosted elsewhere without the express permission from Taylor \& Francis (Routledge). 
generative role models for their children and passing on their wisdom to others as a form of restitution. Exoffenders sought to manage the shame and guilt that accompanied their criminal past and resultant family absences:

So, now I'm trying to do my best, to just be a father and show my son how to be a man, because he's 21 , but he didn't get a chance to learn. He learn it on his own. And a lot of stuff is on his mind right now. He did good. A lot of kids his age would, with a father locked up, a lot of kids thinking that slick. My daddy locked up, that's slick. I told him a long time ago, "I never want you to see the penitentiary." Being locked up don't make you slick, don't make you hard. It messes up your life. It took a lot of things from me. (Damian)

Through sharing his story and prison experiences with his child, Damian had a "constant reminder of the purpose of reform" (Maruna, 2001, p. 124). His newfound role as a present father, a mentor, and teacher provided fulfillment and meaning while simultaneously reminding Damian of his past and how much time he had lost. The reconstruction of one's life story into a moral tale is likely a significant element of reform maintenance, and respondents narrated these tales in a variety of ways.

\section{Accounts of Reentry as Reconstruction}

A number of respondents in this study transitioned to being generative role models for others, taking on the role of parental figure, counselor, advocate, minister, or activist; they accounted for successful reentry and reform through reconstruction ( $n 1 / 413$; eight women, five men). For some, new identities were created after experiencing a turning point or a bottoming out that triggered role exit. Instead of shedding deviant identities however, respondents embraced them in order to generate new careers and future opportunities, and develop a redemptive self. In fact, a few interviewees were now employees or volunteers at the nonprofits in this study. Criminal records and prison stints were reframed as credentialing experiences rather than restrictions (also see Hlavka et al., 2015): 
NOT THE PUBLISHED VERSION; this is the author's final, peer-reviewed manuscript. The published version may be accessed by following the link in the citation at the bottom of the page.

Jean (female): All of my jobs have been community-based jobs. Most of them has been outreach. I love working out in the community. I worked as a Harm Reduction Specialist...I work with children Upfront Program working with Goodwill, working with custodial parents-not custodial parents-mainly fathers, working with them, helping them understand the importance of the children, being a case manager. In fact, I am a case manager now working with the W-2 program, so it's always been around working with people.

Interviewer: And, your stigma hasn't hurt you in employment in these areas?

Jean: No, in fact, it is more so-in some areas it has helped me because I am mentoring right now and because of where I come from.

Like Brown's (1991b) "professional-ex," respondents in our study embraced deviant biographies as an occupational strategy, using past criminal offending and punishment as a way to connect with clients and provide blueprints for how successful reentry can take place. Generative pursuits often embodied collective action as well as rehabilitating other exoffenders or working with high-risk populations. Respondents were hopeful and confident that they could make change for themselves and their communities. They created and maintained connections to something larger than the self-they were youth mentors, participated in gang outreach programming, and spoke to church congregations and current inmates about their life experiences:

At first I started out, I told [the youth group] my conviction, how long I did, and I was telling them about the justice system, I told them how the words and how they-'cause the majority of them was minority. So, I told them how they look at your race, and they look at certain things to convict you or give you time, they look at your family to see if they supportive, and if your family care about you. They look at your past, you know. And I explained to them why you shouldn't sell drugs and rob people and go down that path cause this is what's gonna happen. (Ladelle, male)

Importantly, respondents in our study were quick to remark that that becoming a professional-ex is not appropriate for all released prisoners as it can be especially demanding and challenging: 
NOT THE PUBLISHED VERSION; this is the author's final, peer-reviewed manuscript. The published version may be accessed by following the link in the citation at the bottom of the page.

I think some of the guys are sincere, but it takes more than just, "I want to do it." It takes education. You got incarcerated. Sure, you know what it is like in prison and you probably know what it takes to sit down and talk to another exoffender, but it's more than that. (Ronald, male)

Ronald continued to explain to the interviewer that counseling and mentoring take sacrifice, sincerity, and education:

You can stand up before a group and talk all day, but if you don't have the education and the know-how to present and get that across and build confidence up in the people you are trying to reach, it's not going to last long, and I think that's the reason we have such a recidivism of people going back to prison.

Thus, past experiences alone were insufficient to preach the gospel of personal growth, transformation, and reintegration.

Generative roles afforded meaning and achievement in one's life. Helping others was an accepted metanarrative through which exoffenders established conventional roles and purpose, convincing both themselves and others of their genuine and committed reform efforts. Respondents shifted their concern from themselves outward, focusing on the well-being of friends, family, and others more generally. Respondents were optimistic, described a strong sense of control over their future, derived meaning from their criminal past, and were other-oriented. Reentry was achievable by giving back to others. As Maruna suggested, generativity indeed provided fulfillment for optimistic respondents who could make good and inspire others through meaningful careers or "higher positions" in life. For some, a higher position meant evangelizing or becoming ministers themselves:

Today, you know, I'm a man of God. I represent Jesus Christ, you know. I am a minister, I have been called into the ministry. I am a man that wants to give back. You know, I love working in the community, I love working and helping people to just see that there is a better way for me. You know, I want people to experience what I experience in Jesus, but the freedom. I'm not bound up by anything no more and I walk in total freedom.... I do Bible Study down at the prison, I have been doing prison ministry for the last seven or eight years. If someone asks me to come and speak at a drug and alcohol program or whatever, 
I go. You know, because I want people to know about the Lord and what he can do. (Chris, male)

Other respondents invoked a sense of communal consciousness and desired to enter occupational fields dedicated to helping such as prison counselors. Keisha (female) explained that some women at [the woman's center] spoke about getting the information packet about clemency and she decided to take action: "I want to have a higher position in life as far as now, I just don't want a job." Sharon (female), too, wanted to work for the Department of Corrections helping individuals reintegrate into their communities after incarceration, and Shevon (female) aimed to benefit future generations by becoming a domestic violence counselor. Respondents like these were optimistic about their futures and their capacity to change or work within the system for the benefit of others.

Social support was essential to the maintenance of redemptive scripts. Not only did loved ones and family reaffirm the transformation and redemption narrative our respondents articulated but they also supported role acquisition and change, encouraged participation in programs, and promoted connection to communities. Sharon, for example, spoke about service and volunteer work in her community, and how her experience testifying at the Wisconsin State Capitol Building gave her an increased sense of belonging:

I went to Madison to testify about a bill that's trying to be passed [where they can discriminate based on your felony record] and was told by a Senator, thank you for standing up for that, thank you for giving a face to what where trying to prevent and it's like, I have that. I don't feel like an outcast in my society.

Sharon further spoke about how an important individual in her life contributed to the reconstruction of her formerly spoiled identity:

I am still searching for work. Something in the youth counselor field, mentoring field, speaking engagements...[she] started me off with some speaking engagements and everybody loved them. Every place asked me to come back. And now, the Milwaukee Violence Free Zone and Latino Community Center, they are giving me a shot to try to do something. 
Other-centered pursuits provided respondents with a sense of connection to their communities, their families, and their faith. Reaching positions of leadership in outreach organizations was especially meaningful, as it not only demonstrated a firm commitment to the generative narrative, but also success in professional pursuits.

\section{Discussion}

With incarceration rates at historical highs, the process of reentry remains a significant dilemma for social workers, scholars, and policy makers alike. The transition from custody to the community is challenging, and individuals have a variety of complex needs upon release. Findings from this study show that social and emotional support-from peers, family, intimate partners, spiritual leaders, and other professionals within the community-accounted for successful reentry among men and women from various backgrounds and social locations. This research adds to a growing body of work that critiques one-size-fits-all models of reentry assistance. Fragmenting individuals into problem areas rather than incorporating a holistic perspective that focuses on continuity of care is, at best, shortsighted. Ultimately, our article identifies the possibility of prison as a transforming experience that opens up the potential for positive change. To assist in meaningful change, inmates need purpose in their lives, be it God, family, or selfactualization, and programming is needed to assist in this change. Prisons could capitalize on this by providing opportunities for developing peer and mentor relationships that foster personal change (Boehm, 2014) and partnerships between individuals and reentry programs prior to release. Discussions of faith and family were salient for many respondents and generated intense emotions, including guilt, shame, and hope. Acceptance likely becomes the hook for change in this scenario, and the successful transition from prison to life in the community must begin inside prison walls. Reentry research should address how preprison characteristics and in-prison experiences affect trajectories postprison. This process requires understanding how spiritual development, relationships, and community acceptance provide meaning and role commitments. 
Faith-based prison programs can provide hope for incarcerated women and men because core religious teachings include forgiveness and acceptance for those who repent. Religious conversions are an accepted meta-narrative among inmates (see Maruna et al., 2006; Zaitzow \& Jones, 2013) because it provides an opportunity to atone for one's sins but also aids in identity transformations. Faith-based programs that focus on redemption and reverence are important, but they ought to also strengthen efforts to assist individuals with housing issues, employment, and integrative social support. For example, faith groups create membership and belonging among inmates alongside the social support necessary for transition outside. That support often comes from meeting chaplains who conduct services or volunteers who visit the prison (O'Brien, 2001). Clone and DeHart (2014) note that because chaplains and volunteers are integral support systems for many inmates, developing additional skills among them could be an effective way to promote successful reintegration. Better coordination between chaplaincy and outside faith groups is needed as exoffenders strive to maintain their connections and support systems while simultaneously struggling to find work and housing on the outside.

Similarly, maintaining and repairing relationships with family members is a key component of successful reentry. Much of the research on the importance of personal identity, healing, and connections to family and children has focused on incarcerated women (Clone \& DeHart, 2014; Heidemann, Cederbaum, \& Martinez, 2014; Herrschaft et al., 2009). While a significant body of work shows bonds to work, marriage, and child-rearing can decrease the likelihood of recidivism (Gottfredson \& Hirschi, 1990; Laub \& Sampson, 2003; Sampson \& Laub, 1993; Warr, 1998), little work has specifically highlighted the importance of emotional bonds for incarcerated men. Our study draws attention to the importance of relational support for men returning to their communities perhaps especially when traditional hooks for change, like employment, are elusive. It was just as common for men as for women in our study to rely on emotional support despite literature that emphasizes incarcerated men's material and external validation commitments and women's internal, relational transformations (e.g., O'Brien, 2001). Family is an important motivator and anchor for continued transformation. Providing 
meaningful visitation between inmates and family members, furloughs, use of family cottages, and counseling services (see Costa, 2003; Ekunwe, 2007, 2011) is essential to improving and maintaining family relations. If trained, chaplains, faith-based volunteers, and other professionals are potential sources for cost-effective family counseling. Social bonds and healthy relationships with loved ones and community are crucial because they maintain change over time.

Many men and women in prison are also involved in community service work and some respondents in this study embraced their deviant biographies to rehabilitate or help others. Exoffenders were determined to contribute to, and hoped to be accepted by, society. Helping others provided purpose; it was a way to legitimate both their past crimes and present efforts at reform. In his work, Maruna (2001) found that individuals who desisted from crime underwent a process of transformation whereby concern shifted from themselves outward to a greater concern for the well-being of friends, family, and others more generally. Social support beyond faith-based communities is also needed, as networking between agencies can better address the needs of exoffenders and their families as they navigate the structural and interpersonal barriers to reentry. Exoffenders seek to make sense of their lives in ways that are widely recognizable, legitimate, and maintain self-esteem (Maruna et al., 2006). This study therefore supports corrections that focus on offenders' perceptions through therapy or counseling programs (Wilson, Bouffard, \& Mackenzie, 2005) in order to explore viable options for identity transformation. In this way, peer-to-peer programs (Heidemann et al., 2014) may facilitate successful reentry, perhaps especially when familial ties have been broken. Prison-based counseling and treatment can provide skills prior to release, and mentoring could enhance coordination of services (see Ekunwe \& Jones, 2011; Zaitzow \& Jones, 2013). For example, several states have implemented policies for engaging families in reentry Connecticut offers in-prison parenting courses and visitation assistance and Michigan holds family reunification sessions (diZerega, Carter, \& Giguere, 2010). Successful reentry does not occur in isolation but through connections with and acceptance from others and is likely essential for long-term desistance and reintegration. 
NOT THE PUBLISHED VERSION; this is the author's final, peer-reviewed manuscript. The published version may be accessed by following the link in the citation at the bottom of the page.

\section{Limitations}

Our findings should be interpreted with some caution, as our sample differs from the general population of released prisoners in a few notable ways. The average age of parolees is 34 years (Petersilia, 2003); our sample is markedly older (40.5 years). Our respondents are better educated $(65.8 \%$ reported some college), we oversampled for women, and the majority of respondents are Black despite efforts to actively recruit Latino/a and white respondents. Our sampling approach was not driven by generalizability, however. Because rates of incarceration have increased for Whites, women, and Latinos/as (Warren, Gelb, Horowitz, \& Riordan, 2008), we aimed to elicit a wide range of perceptions to better understand how exoffenders accounted for successful reentry. Our purposive sampling strategy utilized community nonprofit agencies in Milwaukee, WI, dedicated to serving and assisting exoffenders aiming to successfully reenter and reintegrate into their communities. Respondents in our sample were likely committed to this endeavor, evidenced by their voluntary participation in the programs, and thus do not necessarily represent those individuals who are more transient or who have not sought services. While our sampling strategy yielded a diverse group of formerly incarcerated women and men deemed successes, we cannot generalize the identified themes to the larger population of released exoffenders. Future studies should expand on this work by interviewing women and men who are not affiliated with a service agency to examine the significance of support sources, both instrumental and relational. Further, our cross-sectional design does not allow us to speak to whether there was a progression of attempted individual transformations and role shifts prior to those that were deemed to be the source of success for respondents. Therefore, a second wave of data collection is necessary to investigate how accounts might change over time based on life changes and possible relapse. Only longitudinal work is able to remedy some of these issues.

\section{Notes}

1. Some AODA sessions are court mandated.

2. Complete interview guide available upon request.

Journal of Offender Rehabilitation, Vol. 54, No. 6 (2015): pg. 406-428. DOI. This article is @ Taylor \& Francis (Routledge) and permission has been granted for this version to appear in e-Publications@Marquette. [Taylor \& Francis (Routledge) does not grant permission for this article to be further copied/distributed or hosted elsewhere without the express permission from Taylor \& Francis (Routledge). 
3. The study was reviewed and approved by both reentry programs and associated Institutional Review Boards. Human Subject Protocol and data protections were taken to assure confidentiality for all respondents including pseudonyms and unique code numbers accessible only to the primary investigators.

\section{Acknowledgments}

The authors are thankful for the support and participation of members and participants of the nonprofit prison reentry organizations located in Milwaukee, WI.

\section{Funding}

We are grateful for the financial support from two Marquette University regular research grants (IRB protocol numbers HR-910 and HR-1966).

\section{References}

Apel, R., \& Sweeten, G. (2010). The impact of incarceration on employment during the transition to adulthood. Social Problems, 57, 448-479. doi: 10.1525/sp.2010.57.3.448

Boehm, S. (2014). Exploring the roles of redemption, agency, and motivation in two groups of high-risk felony probations. Journal of Qualitative Criminal Justice and Criminology, 2, 268-298.

Braithwaite, J. (1989). Crime, shame and reintegration. Cambridge, MA: Cambridge University Press.

Brown, D. (1991a). Preprofessional socialization and identity transformation: The case of the professional ex-. Journal of Contemporary Ethnography, 20, 157-178. doi:10.1177/089124191020002002

Brown, D. (1991b). The professional ex-: An alternative for exiting the deviant career. The Sociological Quarterly, 32, 219-230. doi: 10.1111/j.1533-8525.1991.tb00354.x

Bushway, S., Piquero, A. R., Broidy, L. M., Cauffman, E., \& Mazerolle, P. (2001). An empirical framework for studying desistance as a process. Criminology, 39, 491-516. doi:10.1111/j.1745-9125.2001.tb00931.x

Carson, A. (2014). Prisons in 2013 (Report No. NCJ 247282). Washington, DC: Bureau of Justice Statistics, U.S. Department of Justice.

Carson, A., \& Golinelli, D. (2014). Prisoners in 2012: Trends in admissions and releases, 1991-2012 (Report No. NCJ 243920). Washington, DC: Bureau of Justice Statistics, U.S. Department of Justice. 
NOT THE PUBLISHED VERSION; this is the author's final, peer-reviewed manuscript. The published version may be accessed by following the link in the citation at the bottom of the page.

Clone, S., \& DeHart, D. (2014). Social support networks of incarcerated women: Types of support, sources of support, and implications for reentry. Journal of Offender Rehabilitation, 53, 503-521. doi: $10.1080 / 10509674.2014 .944742$

Cohen, A. K. (1965). The sociology of the deviant act: Anomie theory and beyond. American Sociological Review, 30, 5-14. doi: $10.2307 / 2091770$

Costa, R. D. (2003). Now I lay me down to sleep: A look at overnight visitation rights available to incarcerated mothers. New England Journal on Criminal and Civil Confinement, 29, 67-98.

diZerega, M., Carter, M., \& Giguere, R. (2010). Engaging offenders' families in reentry. Washington, DC: Office of Justice Programs, Department of Justice.

Durose, M., Cooper, A., \& Synder, H. (2014). Special report: Recidivism of prisoners released in 30 states in 2005: Patterns from 2005-2010. Washington, DC: U.S. Department of Justice.

Ekunwe, I. (2007). Gentle justice: Analysis of open prison systems in Finland. Tampere, Finland: Tampere University Press.

Ekunwe, I. (2011). Re-entering society begins prior to release. In I. Ekunwe \& R. Jones (Eds.), Global perspectives on re-entry (pp. 414-442). Tampere, Finland: Tampere University Press.

Ekunwe, I., \& Jones, R. (2011). Doing re-entry: Accounts of post-prison release in Finland and the United States. In I. Ekunwe \& R. Jones (Eds.), Global perspectives on re-entry, (pp. 443-469). Tampere, Finland: Tampere University Press.

Gadd, D., \& Farrall, S. (2004). Criminal careers desistance and subjectivity: Interpreting men's narratives of change. Theoretical Criminology, 8, 123-156. doi: $10.1177 / 1362480604042241$

Gergen, K. (1999). An invitation to social construction. London, England: Sage Publications.

Giddens, A. (1991). Modernity and self-identity: Self and society in the late modern age. Standford, CA: Stanford University Press.

Giordano, P. C., Cernkovich, S. A., \& Rudolph, J. L. (2002). Gender, crime, and desistance: Toward a theory of cognitive transformation. American Journal of Sociology, 107, 990-1064. doi:10.1086/343191

Glaser, B., \& Strauss, A. (1967). The discovery of grounded theory: Strategies for qualitative research. Chicago, IL: Aldine Publication Company.

Glaze, L. E., \& Kaeble, D. (2014). Correctional Populations in the United States, 2013 (Report No. NCJ 248479). Washington, DC: Bureau of Justice Statistics Bulletin, U.S. Department of Justice.

Goffman, I. (1959). The presentation of self in everyday life. Garden City, NJ: Doubleday-Anchor Books.

Journal of Offender Rehabilitation, Vol. 54, No. 6 (2015): pg. 406-428. DOI. This article is @ Taylor \& Francis (Routledge) and permission has been granted for this version to appear in e-Publications@Marquette. [Taylor \& Francis (Routledge) does not grant permission for this article to be further copied/distributed or hosted elsewhere without the express permission from Taylor \& Francis (Routledge). 
NOT THE PUBLISHED VERSION; this is the author's final, peer-reviewed manuscript. The published version may be

accessed by following the link in the citation at the bottom of the page.

Goffman, I. (1963). Stigma: On the management of spoiled identity. Englewood Cliffs, NY: Prentice Hall.

Gottfredson, M., \& Hirschi, T. (1990). A general theory of crime. Stanford, CA: Stanford University Press.

Gubrium, J., \& Holstein, J. (1997). The new language of qualitative method. Oxford, England: Oxford University Press.

Gubrium, J., \& Holstein, J. (1998). Narrative practice and the coherence of personal stories. The Sociological Quarterly, 39, 163-187. doi:10.1111/j.1533-8525.1998.tb02354.x

Harding, D. (2003). Jean Valjean's dilemma: The management of ex-convict identity in the search for employment. Deviant Behavior, 24, 571-595. doi: $10.1080 / 713840275$

Heidemann, G., Cederbum, J. A., \& Martinez, S. (2014). "We walk through it together": The importance of peer support for formerly incarcerated women's success. Journal of Offender Rehabilitation, 53, 522-542. doi: $10.1080 / 10509674.2014 .944741$

Herrschaft, B. A., Veysey, B. M., Tubman-Carbone, H. R., \& Christian, J. (2009). Gender differences in the transformation narrative: Implications for revised reentry strategies for female offenders. Journal of Offender Rehabilitation, 48, 463-482. doi: $10.1080 / 10509670903081250$

Hlavka, H. R., Wheelock, D., \& Cossyleon, J. E. (2015). Narratives of commitment: Looking for work with a criminal record. The Sociological Quarterly, 56, 213-236. doi:10.1111/tsq.12086

Irwin, J. (1970). The felon. Englewood Cliffs, NY: Prentice Hall.

Johnson, B. R., Larson, D. B., \& Pitts, T. C. (1997). Religious programs, institutional adjustment, and recidivism among former inmates in prison fellowship programs. Justice Quarterly, 14, 145-166. doi:10.1080/07418829700093251

Jones, R., \& Schmid, T. (2000). Doing time: Prison experiences and identity among first- time inmates. Stanford, CT: Jai Press.

Kaufman, J., \& Johnson, C. (2004). Stigmatized individuals and the process of identity. The Sociological Quarterly, 45, 807-833. doi:10.1111/j.15338525.2004.tb02315.x

La Vigne, N., Visher, C., \& Castro, J. (2004). Chicago prisoners' experiences returning home. Washington, DC: Urban Institute.

Laub, J. H., Nagin, D. S., \& Sampson, R. J. (1998). Trajectories of change in criminal offending: Good marriages and the desistance process. American Sociological Review, 63, 225-238. doi:10.2307/2657324

Laub, J. H., \& Sampson, R. J. (2001). Understanding desistance from crime. In M. Tonry (Ed.), Crime and justice: A review of research (pp. 1-69). Chicago, IL: University of Chicago Press.

Journal of Offender Rehabilitation, Vol. 54, No. 6 (2015): pg. 406-428. DOI. This article is @ Taylor \& Francis (Routledge) and permission has been granted for this version to appear in e-Publications@Marquette. [Taylor \& Francis (Routledge) does not grant permission for this article to be further copied/distributed or hosted elsewhere without the express permission from Taylor \& Francis (Routledge). 
NOT THE PUBLISHED VERSION; this is the author's final, peer-reviewed manuscript. The published version may be

accessed by following the link in the citation at the bottom of the page.

Laub, J. H., \& Sampson, R. J. (2003). Shared beginnings, divergent lives: Delinquent boys to age 70. Cambridge, MA: Harvard University Press.

Maruna, S. (2001). Making good: How ex-convicts reform and rebuild their lives. Washington, DC: American Psychological Association.

Maruna, S., \& LeBel, T. (2003). Welcome home? Examining the reentry court concept from a strengths-based perspective. Western Criminology Review, 4, 91-107.

Maruna, S., LeBel, T., Naples, M., \& Mitchell, N. (2009). Looking-glass identity transformation: Pygmalion and Golem in the rehabilitation process. In B. Veysey, J. Christian, \& D. J. Martinez (Eds.), How offenders transform their lives (pp. 30-55). London: Willan Press.

Maruna, S., Wilson, L., \& Curran, K. (2006). Why God is often found behind bars: Prison conversion and the crisis of self-narrative. Research in Human Development, 3, 161-184. doi:10.1207/s15427617rhd0302\&3_6

McAdams, D. P. (1993). The stories we live by: Personal myths and the making of the self. New York, NY: William Morrow.

Mead, G. H. (1934). Mind, Self, and Society: From the Standpoint of a Social Behaviorist. Chicago, IL: University of Chicago.

Morse, J., Barrett, M., Mayan, M., Olson, K., \& Spiers, J. (2002). Verification strategies for establishing reliability and validity in qualitative research. International Journal of Qualitative Methods, 1, 1-19.

Nelson, M., Deess, P., \& Allen, C. (1999). The first month out: Postincarceration experiences in New York City. New York, NY: Vera Institute of Justice.

O'Brien, P. (2001). Making it in the 'free world': Women in transition from prison. New York, NY: State University of New York Press.

Pager, D., Western, B., \& Bonikoswki, B. (2009). Discrimination in a low-wage labor market: A field experiment. American Sociological Review, 74, 779-799. doi:10.1177/000312240907400505

Pager, D., Western, B., \& Sugie, N. (2009). Sequencing disadvantage: Barriers to employment facing young black and white men with criminal records. Annals of the American Academy of Political and Social Science, 623(1), 195-213.

Patton, M. (1990). Qualitative evaluation and research methods. Newbury Park, CA: Sage.

Petersilia, J. (2003). When prisoners come home: Parole and prisoner reentry. Oxford, NY: Oxford University Press.

Pew Center on the States. (2008). One in 100: Behind bars in America. Washington, DC: The Pew Charitable Trusts.

Richards, S., \& Jones, R. (2004). Beating the perpetual incarceration machine: Overcoming structural impediments to re-entry. In S. Maruna \& R. Immarigeon (Eds.), After crime and punishment:

Journal of Offender Rehabilitation, Vol. 54, No. 6 (2015): pg. 406-428. DOI. This article is @ Taylor \& Francis (Routledge) and permission has been granted for this version to appear in e-Publications@Marquette. [Taylor \& Francis (Routledge) does not grant permission for this article to be further copied/distributed or hosted elsewhere without the express permission from Taylor \& Francis (Routledge). 
NOT THE PUBLISHED VERSION; this is the author's final, peer-reviewed manuscript. The published version may be accessed by following the link in the citation at the bottom of the page.

Pathways to offender reintegration (pp. 201-232). Portland, OR: Willan Publishing.

Richie, B. (2001). Challenges incarcerated women face as they return to their communities: Findings from life history interviews. Crime \& Delinquency, 47, 368-389. doi:10.1177/0011128701047003005

Ross, J. I., \& Richards, S. (2002). Convict criminology. Belmont, CA: Wadsworth.

Sampson, R., \& Laub, J. (1993). Crime in the making: Pathways and turning points through life. Cambridge, MA: Harvard University Press.

Schmid, T., \& Jones, R. (1991). Suspended identity dialectic: Identity transformation in a maximum security prison. Symbolic Interaction, 14, 415-432.

Solomon, A., Roman, C. G., \& Waul, M. (2001). Summary of focus group with exprisoners in the district: Ingredients for successful reintegration. Washington, DC: Urban Institute.

Travis, J. (2001). But they all come back: Rethinking prisoner reentry. Corrections Management Quarterly, 5, 23-33.

Travis, J., \& Petersilia, J. (2001). Reentry reconsidered: A new look at an old question. Crime \& Delinquency, 47, 291-313. doi: $10.1177 / 0011128701047003001$

Travis, J., \& Waul, M. (2003). Prisoners once removed: The impact of incarceration and reentry on children, families, and communities. Washington, DC: Urban Institute Press.

Uggen, C. (2000). Work as a turning point in the life course of criminals: A duration model of age, employment, and recidivism. American Sociological Review, 65, 529-546. doi:10.2307/2657381

Uggen, C., Manza, J., \& Thompson, M. (2006). Citizenship, democracy, and the civic reintegration of criminal offenders. The Annals of the American Academy of Political and Social Science, 605, 281-310.

Uggen, C., \& Thompson, M. (2003). The socioeconomic determinants of illgotten gains: Within-person changes in drug use and illegal earnings. American Journal of Sociology, 109, 146-185. doi:10.1086/378036

Visher, C., Kachnowski, V., La Vigne, N., \& Travis, J. (2004). Baltimore prisoners' experiences returning home. Washington, DC: The Urban Institute, Justice Policy Center.

Visher, C., Yahner, J., \& La Vigne, N. G. (2010). Life after prison: Tracking the experiences of male prisoners returning to Chicago, Cleveland, and Houston. Washington, DC: The Urban Institute, Justice Policy Center.

Visher, C. A., \& Travis, J. (2003). Transitions from prison to community: Understanding individual pathways. Annual Review of Sociology, 29, 89-113. doi:10.1146/annurev.soc.29.010202.095931

Journal of Offender Rehabilitation, Vol. 54, No. 6 (2015): pg. 406-428. DOI. This article is @ Taylor \& Francis (Routledge) and permission has been granted for this version to appear in e-Publications@Marquette. [Taylor \& Francis (Routledge) does not grant permission for this article to be further copied/distributed or hosted elsewhere without the express permission from Taylor \& Francis (Routledge). 
Wakefield, S., \& Wildeman, C. (2014). Children of the prison boom: Mass incarceration and the future of American inequality. Oxford, NY: Oxford University Press.

Warr, M. (1998). Life-course transitions and desistance from crime. Criminology, 36, 186-216. doi:10.1111/j.1745-9125.1998.tb01246.x

Warren, J., Gelb, A., Horowtiz, J., \& Riordan, J. (2008). One in 100: Behind bars in America 2008. Washington, DC: The Pew Center on the States.

Wheelock, D. (2005). Collateral consequences and racial inequality: Felon status restrictions as a system of disadvantage. Journal of Contemporary Criminal Justice, 21, 82-90. doi:10.1177/1043986204271702

Wheelock, D., \& Uggen, C. (2008). Race, poverty and punishment: The impact of criminal sanctions on racial, ethnic, and socioeconomic inequality. In D. Harris \& A. C. Lin (Eds.), The colors of poverty: Why racial and ethnic disparities persist (pp. 261-292). New York, NY: Russell Sage Foundation.

Wheelock, D., Uggen, C., \& Hlavka, H. (2011). Employment restrictions for individuals with felon status and racial inequality in the labor market. In I. O. Ekunwe \& R. S. Jones (Eds.), Global perspectives on re-entry (pp. 278-310). Tampere, Finland: University of Tampere Press.

Wilson, D. B., Bouffard, L. A., \& Mackenzie, D. L. (2005). A quantitative review of structured, group-oriented, cognitive-behavioral programs for offenders. Criminal Justice and Behavior, 32, 172-204. doi: $10.1177 / 0093854804272889$

Zaitzow, B. H. \& Jones, R. S. (2013). Redemption from the inside-out: The power of faith-based programming, in L. Gideon (ed.), Special needs offenders in correctional institutions (pp. 319-344). Thousand Oaks, CA: Sage Publications.

Address correspondence to Professor Heather Hlavka, Marquette University, Social and Cultural Sciences, 410 Lalumiere Hall, P.O. Box 1881, Milwaukee, WI 53201. E-mail: heather.hlavka@mu.edu 